\title{
High-performance liquid chromatographic enantioseparation of unusual amino acid derivatives with axial chirality on polysaccharide-based chiral stationary phases
}

\author{
Pilar López-Ram-de-Víu*, José A. Gálvez, María D. Díaz-de-Villegas \\ Departamento de Catálisis y Procesos Catalíticos, Instituto de Síntesis Química y \\ Catálisis Homogénea (ISQCH), CSIC - Universidad de Zaragoza, c/ Pedro Cerbuna 12, \\ E-50009 Zaragoza, Spain \\ *Corresponding author Tel: +34 976 762274; fax +34 976 761202, e-mail: \\ pilopez@unizar.es,
}

\begin{abstract}
The successful enantioseparation of axially chiral amino acid derivatives containing a cyclohexylidene moiety on an analytical and semipreparative scale was achieved for the first time by HPLC using polysaccharide-based chiral stationary phases. Racemic methyl $\mathrm{N}$-benzoylamino esters, easily obtained by methanolysis of the corresponding $5(4 H)$ oxazolones, were subjected to chiral HPLC resolution using chiral stationary phases based on immobilized 3,5-dimethylphenylcarbamate derivatives of amylose (Chiralpak ${ }^{\circledR}$ IA column) or cellulose (Chiralpak ${ }^{\circledR}$ IB column). The behaviour of both selectors under different elution conditions was evaluated and compared. The amylose column showed better performance than the cellulose column for all enantiomers tested.
\end{abstract}

The semipreparative resolution of axially chiral amino acid derivatives with different side chains has been achieved on a $250 \mathrm{~mm} \times 20 \mathrm{~mm}$ ID Chiralpak ${ }^{\circledR}$ IA column using the appropriate mixture of $n$-hexane/chlorofom/ethanol as eluent by successive injections of a solution of the sample in chloroform. Using this protocol up to $120 \mathrm{mg}$ of each enantiomer of the corresponding axially chiral amino acid derivative were obtained from $300 \mathrm{mg}$ of racemate. [( $\mathrm{Sa})-2 \mathrm{a}, 105 \mathrm{mg}$; (Ra)-2a, $60 \mathrm{mg}$, [(Sa)-2b, $105 \mathrm{mg}$; (Ra)-2b, $90 \mathrm{mg}$, [(Sa)- 2c, $120 \mathrm{mg}$; (Ra)-2c, $100 \mathrm{mg}]$.

Keywords: Axial dissymmetry. Enantiomer separation. HPLC. Polysaccharide-based chiral stationary phase. Unusual amino acid.

\section{Introduction}

$\alpha$-Amino acids are considered to be amongst the most important building blocks in chemistry. Apart from being the structural subunits of proteins, peptides and many secondary metabolites they are versatile chiral starting materials for the synthesis of peptides, alkaloids, antibiotics and more complex molecules with biological activities [1-3]. Amino acids have also been used as chiral auxiliaries, ligands and catalysts in asymmetric synthesis_[4-8].

The design and synthesis of new $\alpha$-amino acids with unusual structural features that can provide peptides with improved biological properties, more versatile chiral 
synthons or catalysts capable of inducing higher asymmetry is a subject of continued interest [9-14].

In most of the newly designed chiral amino acids, chirality relies on the presence of one or more a stereogenic atoms. Chirality may arise from another type of molecular asymmetry, namely the presence of a chiral axis. In this context, atropoisomeric $\alpha$ amino acids with a biaryl axis in their structure have been synthesised [15-19] and resolved [20-21], and the behaviour of model peptides that incorporate these unusual amino acids has been studied in detail . [22-27]

In the course of our research we prepared racemic (4-substituted cyclohexylidene)glycines (Figure 1), another family of axially chiral amino acids, which can be considered as elongated structural analogues of parent amino acids, and small peptides derived from them [28-30] We became interested in the development of a practical procedure for the isolation of these axially chiral amino acids in enantiomerically pure form.

High-performance liquid chromatography using chiral stationary phases is a powerful tool for the direct analysis of enantiomers. High-performance liquid chromatography on a semipreparative scale is considered to be one of the most efficient approaches to obtain small amounts of enantiomerically pure compounds in a reasonable time [31-33] which is of paramount importance in pharmaceutical research and drug development. Different protocols to perform the enantiomeric separation of chiral nonproteinogenic amino acids with stereogenic atoms by high-performance liquid chromatography have been described [34]. As far as axially chiral amino acids are concerned, the analytical resolution of atropoisomeric $\alpha$-amino acid Bin has been performed on a $\beta$-cyclodextrin-based chiral stationary phase, ChiralDex [35]. Nevertheless, to the best of our knowledge work has not been published on the development of enantioselective chromatographic protocols for the quantitative determination and preparative resolution of axially chiral amino acids containing a cyclohexylidene moiety [36].

Our efforts were focused on developing chromatographic protocols to perform the enantioseparation of axially chiral (4-substituted cyclohexylidene)glycine derivatives on an analytical and semipreparative scale by high performance liquid chromatography using chiral stationary phases. Among the different chiral stationary phases available, those based on polysaccharides are exceptionally versatile for the analytical separation of many different chiral compounds [37]. In the work described here, chiral stationary phases (CSPs) based on immobilized amylose and cellulose were chosen since they are particularly useful for preparative-scale enantioseparation due to the combination of excellent chiral recognition properties, compatibility with organic solvents and high loading capacity [38, 39]. Moreover, these stationary phases are commercially available.

\section{Experimental}

\subsection{Materials and methods (Chemicals and reagents)}

All the reagents and solvents were reagent grade and were used without further purification unless otherwise specified. $n$-Hexane, isopropanol, ethanol, acetone and chloroform used for HLPC separations were chromoscan grade from LabScan (Avantor Performance Materials Poland S.A, Gliwice, Poland). Reactions were magnetically stirred and monitored by thin-layer chromatography (TLC) on $0.25-\mathrm{mm}$ silica gel plates. UV light, $p$-anisaldehyde, ninhydrin and phosphomolybdic acid sprays were applied for visualization. 5(4H)-Oxazolones 1a, $\mathbf{1 b}$ and 1c were prepared according to our previously described procedure [29]. 


\subsection{Instrumentation}

HPLC separations were carried out on a Waters HPLC system (Waters Corporation, Milford, USA) consisting of an M-600 low-pressure gradient pump, an M2996 photodiode array detector and an M-2487 dual wavelength absorbance detector, to monitor analytical and preparative separations, respectively. The chromatographic data were acquired and processed with Millennium ${ }^{\circledR}$ chromatography manager software (Waters). A rheodine 7125 syringe-loading sample injector was equipped with 20- and $500-\mu \mathrm{L}$ loops for analytical or semipreparative chromatography. Commercially available polysaccharide chiral stationary phases based on amylose tris(3,5dimethylphenylcarbamate), Chiralpak ${ }^{\circledR}$ IA column, and cellulose tris(3,5dimethylphenylcarbamate), Chiralpak ${ }^{\circledR}$ IB column (Chiral Technologies Europe, Illkirch Cedex, France), were used.

The HPLC analytical assays were carried out operating under isocratic conditions at room temperature on Chiralpak ${ }^{\circledR}$ IA and Chiralpak ${ }^{\circledR}$ IB $250 \times 4.6 \mathrm{~mm}$ ID columns. Different binary and ternary mixtures of solvents were used as eluents. Samples were manually injected. The flow rate was $1 \mathrm{~mL} / \mathrm{min}$. The analyte concentration in injected solutions was $5 \mathrm{mg} / \mathrm{mL}$ and the injection volume was $5 \mu \mathrm{L}$. Detection was performed at multiple wavelengths for each compound. The capacity $\left(k^{\prime}\right)$, selectivity $(\alpha)$ and resolution $\left(R_{s}\right)$ factors were calculated according to the equations $k^{\prime}=\left(t_{r}-t_{0}\right) / t_{0}, \alpha=$ $k_{2}^{\prime} / k_{1}^{\prime}, R_{s}=2\left(t_{2}-t_{1}\right) /\left(w_{2}+w_{1}\right)$. Subscripts 1 and 2 refer to the first and second eluted enantiomer, respectively, $t_{r}(r=1,2)$ are their retention times, and $w_{1}$ and $w_{2}$ denote their baseline peak widths; $t_{0}$ is the dead time.

The HPLC semipreparative resolution of compound $\mathbf{2 a - c}$ was carried out operating under isocratic conditions at room temperature on a $250 \times 20 \mathrm{~mm}$ ID Chiralpak ${ }^{\circledR}$ IA column. A ternary mixture of $n$-hexane/ethanol/chloroform was used as the eluent. Injections and collections were made manually. The flow rate was 18 $\mathrm{mL} / \mathrm{min}$ for compound $\mathbf{2 a}$ and $16 \mathrm{~mL} / \mathrm{min}$ for compounds $\mathbf{2 b}$ and $\mathbf{2 c}$. The wavelength for UV detection was 280,290 and $265 \mathrm{~nm}$ for compounds $\mathbf{2 a}, \mathbf{2 b}$ and $\mathbf{2 c}$, respectively. Both the column loading capacity, $W_{\mathrm{s}}$ (defined as the maximum sample mass that the column can hold) and the optimum sample concentration were calculated in each case for the analytical $250 \times 4.6 \mathrm{~mm}$ ID Chiralpak ${ }^{\circledR}$ IA column by injecting increasing amounts of sample at different concentrations.

Melting points were recorded on a Gallenkamp capillary melting point apparatus (Weiss-Gallenkamp, Loughborough, United kindom) in open capillaries and are not corrected.

Optical rotations were measured on a Jasco P-1020 digital polarimeter from (Jasco Corporation, Tokio, Japan). $[\alpha]_{D}$ values are given in units of $10^{-1} \mathrm{deg} \cdot \mathrm{cm} \cdot \mathrm{g}^{-1}$ and concentrations are given in $\mathrm{g} / 100 \mathrm{~mL}$.

FTIR spectra were recorded as nujol dispersions on $\mathrm{NaCl}$ plates or as $\mathrm{KBr}$ pellets using a Thermo Nicolet Avatar 360 FT-IR spectrometer (Thermo Fischer Scientific, Waltham, Massachusetts, USA), $v_{\max }$ values expressed in $\mathrm{cm}^{-1}$ are given for the main absorption bands.

${ }^{1} \mathrm{H}$ NMR and ${ }^{13} \mathrm{C}$ NMR spectra were acquired on a Bruker AV-500 spectrometer, a Bruker AV-400 spectrometer or a Bruker AV-300 spectrometer Bruker-Biospin, Rheinstetten, Germany) operating at 500,400 or $300 \mathrm{MHz}$ for ${ }^{1} \mathrm{H}$ NMR and 125,100 or $75 \mathrm{MHz}$ for ${ }^{13} \mathrm{C}$ NMR at room temperature using a $5-\mathrm{mm}$ probe unless stated otherwise. The chemical shifts ( ) $\delta$ are reported in parts per million from tetramethylsilane with the solvent resonance as the internal standard [40]. [39] The following abbreviations for splitting patterns are reported as s (singlet), d (doublet), $\mathrm{m}$ (multiplet), ddd (doublet of 
doublet of doublets) and br (broad). Coupling constants $(J)$ are quoted in Hertz. ${ }^{13} \mathrm{C}$ Attached Proton Test (APT) spectra were taken to determine the types of carbon signals. High resolution mass spectra were recorded using a Bruker Daltonics MicroToFQ instrument (Bruker Daltonics, Billerica, Massachusetts, USA) from methanolic solutions using the positive electrospray ionization mode (ESI+).

2.3. General procedure for the synthesis and resolution of axially chiral amino acid derivatives rac-2a, rac-2b and rac-2c 2.3.1. Methyl 2-benzamido-2-(4-phenylcyclohexylidene)acetate (rac-2a).

Yield $670 \mathrm{mg}$ (97\%), IR absorptions (nujol) $v_{\max } 3268,1722 ; 1637$,

${ }^{1} \mathrm{H}$ NMR $\left(400 \mathrm{MHz}, \mathrm{CDCl}_{3}\right): \delta=1.66-1.78(\mathrm{~m}, 2 \mathrm{H}), 2.00-2.26(\mathrm{~m}, 4 \mathrm{H}), 2.75-2.85(\mathrm{~m}$, 2H), 3.70 (ddd, $1 \mathrm{H}, J=14.0,5.6,3.2 \mathrm{~Hz}$ ), 3.79 (s, 3H), 7.17-7.23 (m, 3H), 7.28-7.32 $(\mathrm{m}, 2 \mathrm{H}), 7.41$ (brs, 1H), 7.45-7.20 (m, 2H), 7.52-7.57 (m, 1H), 7.85-7.88 (m, 2H), ${ }^{13} \mathrm{C}$ NMR $\left(100 \mathrm{MHz}, \mathrm{CDCl}_{3}\right) \delta=30.2\left(\mathrm{CH}_{2}\right), 31.4\left(\mathrm{CH}_{2}\right), 34.3\left(\mathrm{CH}_{2}\right), 34.8\left(\mathrm{CH}_{2}\right), 44.0$ $(\mathrm{CH}), 52.0\left(\mathrm{CH}_{3}\right), 118.6(\mathrm{C}), 126.2(\mathrm{CH}), 126.7(\mathrm{CH}), 127.2(\mathrm{CH}), 128.4(\mathrm{CH}), 128.6$ $(\mathrm{CH}), 131.9(\mathrm{CH}), 133.8(\mathrm{C}), 145.8(\mathrm{C}), 149.7(\mathrm{C}), 165.5(\mathrm{C}), 166.1(\mathrm{C})$; HRMS $\left(\mathrm{FAB}^{+}\right)$ calcd for $\mathrm{C}_{22} \mathrm{H}_{23} \mathrm{NO}_{3} \mathrm{Na}\left(\mathrm{MNa}^{+}\right)$372.1570; found 372.1567.

$\underline{300} \mathrm{mg}$ of rac-2a dissolved in $\mathrm{CHCl}_{3}(12 \mathrm{~mL})$ were resolved by successive injections of $500 \mu \mathrm{L}$ of solution on a $250 \times 20 \mathrm{~mm}$ ID Chiralpak ${ }^{\circledR}$ IA column and using a ternary mixture $n-\mathrm{Hx} / \mathrm{EtOH} / \mathrm{CHCl}_{3}(86 / 7 / 7)$ as the eluent (flow rate: $18 \mathrm{~mL} / \mathrm{min}$ ). A total of 24 injections were performed, with one injection performed every $12 \mathrm{~min}$. Four separate fractions were collected. The first, second, third and fourth fractions contained, respectively, 100/0 (105 mg), 85/15 (28 mg), 4/96 (72 mg) and 0/100 (60 mg) mixtures of $(S a)-2 a$ and $(R a)-2 a$. $(S a)-2 a$ : White solid, m. p. $=189.8{ }^{\circ} \mathrm{C} ;[\alpha]_{25}^{\mathrm{D}}=45.5(c 0.75$, $\left.\mathrm{CHCl}_{3}\right)$. (Ra)-2a: White solid, m. p. $=189.6^{\circ} \mathrm{C}$; $[\alpha]^{\mathrm{D}}{ }_{25}=-45.4\left(c 0.70, \mathrm{CHCl}_{3}\right)$. Spectroscopic data for $(S a)$-2a and $(R a)$-2a were identical to those given above for the racemic compound.

2.3.2. Methyl 2-benzamido-2-(4-methylcyclohexylidene)acetate (rac-2b). Yield $645 \mathrm{mg}$ (98\%), IR absorptions (nujol) $v_{\max } 3268,1722 ; 1638$,

${ }^{1} \mathrm{H}$ NMR $\left(400 \mathrm{MHz}, \mathrm{CDCl}_{3}\right): \delta=0.89(\mathrm{~d}, 3 \mathrm{H}, J=6.6 \mathrm{~Hz}), 1.11(\mathrm{ddd}, 1 \mathrm{H}, J=13.0,3.6$, $3.6 \mathrm{~Hz}$ ), 1.17 (ddd, $1 \mathrm{H}, J=13.0,3.6,3.6 \mathrm{~Hz}), 1.56-1.68(\mathrm{~m}, 1 \mathrm{H}), 1.76-1.87(\mathrm{~m}, 2 \mathrm{H})$, 1.97 (ddd, $1 \mathrm{H}, J=13.5,13.5,4.5 \mathrm{~Hz}), 2.06(\mathrm{ddd}, 1 \mathrm{H}, J=13.5,13.5,4.3 \mathrm{~Hz}), 2.62$ (ddd, $1 \mathrm{H}, J=14.0,5.7,3.4 \mathrm{~Hz}), 3.41(\mathrm{ddd}, 1 \mathrm{H}, J=14.0,5.5,3.4 \mathrm{~Hz}), 3.74(\mathrm{~s}, 3 \mathrm{H}), 7.38-7.43$ 
(m, 2H), 7.46-7.42 (m, 1H), 7.58 (brs, 1H), 7.81-7.85 (m, 2H); ${ }^{13} \mathrm{C}$ NMR (100 MHz, $\left.\mathrm{CDCl}_{3}\right) \delta=21.5\left(\mathrm{CH}_{3}\right), 29.7\left(\mathrm{CH}_{2}\right), 30.9\left(\mathrm{CH}_{2}\right), 32.0(\mathrm{CH}), 35.3\left(\mathrm{CH}_{2}\right), 35.7\left(\mathrm{CH}_{2}\right), 51.8$ $\left(\mathrm{CH}_{3}\right), 118.5(\mathrm{C}), 127.2(\mathrm{CH}), 128.5(\mathrm{CH}), 131.7(\mathrm{CH}), 133.8(\mathrm{C}), 150.7(\mathrm{C}), 165.6(\mathrm{C})$, $166.3(\mathrm{C})$; HRMS $\left(\mathrm{FAB}^{+}\right)$calcd for $\mathrm{C}_{17} \mathrm{H}_{21} \mathrm{NO}_{3} \mathrm{Na}\left(\mathrm{MNa}^{+}\right) 310.1414$; found 310.1412 . $150 \mathrm{~L}$ of solution on a $250 \times 20 \mathrm{~mm}$ ID Chiralpak ${ }^{\circledR}$ IA column and uns a ternaty $150 \mu \mathrm{L}$ of solution on a $250 \times 20 \mathrm{~mm}$ ID Chiralpak ${ }^{\circledR}$ IA column and using a ternary mixture $n-\mathrm{Hx} / \mathrm{EtOH} / \mathrm{CHCl}_{3}(84 / 4 / 12)$ as the eluent (flow rate: $\left.16 \mathrm{~mL} / \mathrm{min}\right)$. A total of 13 injections were performed, with one injection performed every $20 \mathrm{~min}$. Four separate fractions were collected. The first, second, third and fourth fractions contained, respectively, 98.5/1.5 (105 mg), 85/15 (14 mg), 6/94 (41 mg) and 0/100 (90 mg) mixtures of $(S a)$-2b and $(R a)-2 \mathbf{b}$. $(S a)-2 \mathbf{b}$ : White solid, m. p. $=167-168^{\circ} \mathrm{C} ;[\alpha]_{25}^{\mathrm{D}}=15.8$ (c 0.59, $\left.\mathrm{CHCl}_{3}\right) .(\mathrm{Ra})$-2b: White solid, m. p. $=167-168^{\circ} \mathrm{C} ;[\alpha]^{\mathrm{D}}{ }_{25}=-15.8(c$ 0.55, $\left.\mathrm{CHCl}_{3}\right)$. Spectroscopic data for $(\mathrm{Sa} a \mathbf{- 2 \mathbf { b }}$ and $(\mathrm{Ra})$-2b were identical to those given above for the racemic compound.

2.3.3. Methyl 2-benzamido-2-(4-tert-butylcyclohexylidene)acetate (rac-2c). Yield 545

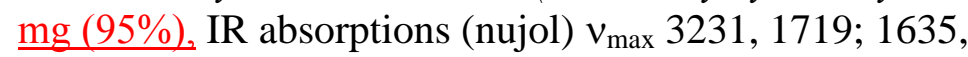

H NMR (400 MHz, $\left.\mathrm{CDCl}_{3}\right): \delta=0.85(\mathrm{~s}, 9 \mathrm{H}), 1.16-1.29(\mathrm{~m}, 3 \mathrm{H}), 1.87-2.04(\mathrm{~m}, 4 \mathrm{H})$, $2.70(\mathrm{ddd}, 1 \mathrm{H}, J=13.6,5.3,2.9 \mathrm{~Hz}), 3.54(\mathrm{ddd}, 1 \mathrm{H}, J=13.6,5.1,2.6 \mathrm{~Hz}), 3.75(\mathrm{~s}, 3 \mathrm{H})$, 7.40-7.45 (m, 2H), 7.48-7.54 (m, 2H), 7.81-7.85 (m, 2H); $\left.{ }^{13} \mathrm{C} \mathrm{NMR} \mathrm{(100} \mathrm{MHz,} \mathrm{CDCl}_{3}\right)$ $\delta=27.6\left(\mathrm{CH}_{3}\right), 28.0\left(\mathrm{CH}_{2}\right), 28.4\left(\mathrm{CH}_{2}\right), 30.3\left(\mathrm{CH}_{2}\right), 31.6\left(\mathrm{CH}_{2}\right), 32.5(\mathrm{C}), 47.6(\mathrm{CH})$, $51.9\left(\mathrm{CH}_{3}\right), 118.2(\mathrm{C}), 127.3(\mathrm{CH}), 128.6(\mathrm{CH}), 131.7(\mathrm{CH}), 133.9(\mathrm{C}), 151.3(\mathrm{C}), 165.7$ (C), 166.4 (C); HRMS (FAB $\left.{ }^{+}\right)$calcd for $\mathrm{C}_{20} \mathrm{H}_{27} \mathrm{NO}_{3} \mathrm{Na}\left(\mathrm{MNa}^{+}\right)$352.1883; found 352.1851 .

$300 \mathrm{mg}$ of rac-2c dissolved in $\mathrm{CHCl}_{3}(4 \mathrm{~mL})$ were resolved by successive injections of $200 \mu \mathrm{L}$ of solution on a $250 \times 20 \mathrm{~mm}$ ID Chiralpak ${ }^{\circledR}$ IA column and using a ternary mixture $n$-Hx/EtOH/ $\mathrm{CHCl}_{3}(92 / 4 / 4)$ as the eluent (flow rate: $16 \mathrm{~mL} / \mathrm{min}$ ). A total of 20 injections were performed, with one injection performed every $13 \mathrm{~min}$. Four separate fractions were collected. The first, second, third and fourth fractions contained, respectively, 100/0 (120 mg), 82/18 (32 mg), 3/97 (40 mg) and 0/100 (100 mg) mixtures of $(S a)-2 c$ and $(R a)-2 c$. $(S a)-2 c:$ White solid, m. p. $=83{ }^{\circ} \mathrm{C} ;[\alpha]^{\mathrm{D}}{ }_{25}=10.2(c 0.54$, $\left.\mathrm{CHCl}_{3}\right)$. (Ra)-2c: White solid, m. p. $=82-83{ }^{\circ} \mathrm{C} ;[\alpha]^{\mathrm{D}}{ }_{25}=-10.8\left(c 0.75, \mathrm{CHCl}_{3}\right)$. Spectroscopic data for $(S a)-2 c$ and $(R a)-2 c$ were identical to those given above for the racemic compound.

\subsection{General procedure for the saponification of axially chiral amino acid derivatives $2 a, 2 b$ and $2 c$}

A mixture of the corresponding racemic or enantiomerically pure $N$-benzoyl amino ester $\mathbf{2 a}-\mathbf{c}(1 \mathrm{mmol})$ in $4 \%$ ethanolic potassium hydroxide $(12 \mathrm{~mL})$ was stirred at room temperature for one day. After concentration of the solution in vacuo, water was added and the aqueous phase was washed with diethyl ether. The aqueous layer was acidified with $1 \mathrm{~N}$ hydrochloric acid and then extracted with dichloromethane. 
Concentration in vacuo of the organic layer resulted in the appearance of a pale yellow solid, which was washed with a small portion of diethyl ether to afford pure samples of the corresponding racemic or enantiomerically pure $N$-benzoyl amino acid $\mathbf{3 a}-\mathbf{c}$. Yields were almost quantitative for $\mathbf{3 a}$ and $\mathbf{3 c}$ and about $90 \%$ for $\mathbf{3 b}$.

2.4.1. 2-Benzamido-2-(4-phenylcyclohexylidene)acetic acid (rac-3a). White solid, IR absorptions $(\mathrm{KBr}) v_{\max } 3303,1713 ; 1647,{ }^{1} \mathrm{H}$ NMR $\left(400 \mathrm{MHz}, \mathrm{DMSO}-d_{6}\right): \delta=1.42-$ $1.63(\mathrm{~m}, 2 \mathrm{H}), 1.90-2.01(\mathrm{~m}, 2 \mathrm{H}), 2.03-2.07(\mathrm{~m}, 2 \mathrm{H}), 2.77-2.83(\mathrm{~m}, 2 \mathrm{H}), 3.53$ (brd, $1 \mathrm{H}$, $J=13.06 \mathrm{~Hz}), 7.15-7.31(\mathrm{~m}, 5 \mathrm{H}), 7.46-7.57(\mathrm{~m}, 3 \mathrm{H}), 7.93-7.96(\mathrm{~m}, 2 \mathrm{H}), 9.70(\mathrm{~s}, 1 \mathrm{H})$, 12.50 (brs, $1 \mathrm{H}) ;{ }^{13} \mathrm{C}$ NMR (100 MHz, DMSO-d $) \delta=29.4\left(\mathrm{CH}_{2}\right), 30.4\left(\mathrm{CH}_{2}\right), 34.2$ $\left(\mathrm{CH}_{2}\right), 34.6\left(\mathrm{CH}_{2}\right), 43.1(\mathrm{CH}), 121.3(\mathrm{C}), 126.20(\mathrm{CH}), 126.6(\mathrm{CH}), 127.5(\mathrm{CH}), 128.2$ $(\mathrm{CH}), 128.3(\mathrm{CH}), 131.4(\mathrm{CH}), 133.7(\mathrm{C}), 145.1(\mathrm{C}), 146.1(\mathrm{C}), 165.6(\mathrm{C}), 166.3(\mathrm{C})$; HRMS $\left(\mathrm{FAB}^{+}\right)$calcd for $\mathrm{C}_{21} \mathrm{H}_{21} \mathrm{NO}_{3} \mathrm{Na}\left(\mathrm{MNa}^{+}\right) 358.1414$; found 358.1389.

(Sa)-3a: White solid, m. p. $(\mathrm{dec})=195-200^{\circ} \mathrm{C} ;[\alpha]^{\mathrm{D}}{ }_{25}=-9.1\left(c 0.33, \mathrm{CH}_{3} \mathrm{OH}\right) .(R a)-3 \mathbf{a}$ : White solid, m. p. $(\mathrm{dec})=195-200{ }^{\circ} \mathrm{C} ;[\alpha]^{\mathrm{D}}{ }_{25}=8.9\left(c 0.32, \mathrm{CH}_{3} \mathrm{OH}\right)$. Spectroscopic data for $(S a)-3 a$ and $(R a)$-3a were identical to those given above for the racemic compound.

2.4.2. 2-Benzamido-2-(4-methylcyclohexylidene)acetic acid (rac-3b). White solid, IR absorptions $(\mathrm{KBr}) v_{\max } 3270,1693 ; 1648,{ }^{1} \mathrm{H}$ NMR $\left(400 \mathrm{MHz}, \mathrm{DMSO}-d_{6}\right): \delta=0.88(\mathrm{~d}$, $3 \mathrm{H}, J=6.4 \mathrm{~Hz}), 0.97-1.12(\mathrm{~m}, 2 \mathrm{H}), 1.55-1.65(\mathrm{~m}, 1 \mathrm{H}), 1.73-1.83(\mathrm{~m}, 2 \mathrm{H}), 1.88$ (ddd, $1 \mathrm{H}, J=13.4,13.4,4.4 \mathrm{~Hz}), 1.98(\mathrm{ddd}, 1 \mathrm{H}, J=13.4,13.4,3.6 \mathrm{~Hz}), 2.58-2.64(\mathrm{~m}, 1 \mathrm{H})$, 3.28-3.36 (m, 1H), 7.45-7.50 (m, 2H), 7.53-7.57 (m, 1H), 7.88-7.92 (m, 2H), $9.60(\mathrm{~s}$, 1H), 12.27 (brs, 1H); ${ }^{13} \mathrm{C}$ NMR (100 MHz, DMSO-d $) \delta=21.7\left(\mathrm{CH}_{3}\right), 29.1\left(\mathrm{CH}_{2}\right), 30.1$ $\left(\mathrm{CH}_{2}\right), 31.6(\mathrm{CH}), 35.2\left(\mathrm{CH}_{2}\right), 35.6\left(\mathrm{CH}_{2}\right), 120.8(\mathrm{C}), 127.6(\mathrm{CH}), 128.4(\mathrm{CH}), 131.5$ $(\mathrm{CH}), 133.8(\mathrm{C}), 146.4(\mathrm{C}), 165.7(\mathrm{C}), 166.4(\mathrm{C})$; HRMS $\left(\mathrm{FAB}^{+}\right)$calcd for $\mathrm{C}_{16} \mathrm{H}_{19} \mathrm{NO}_{3} \mathrm{Na}\left(\mathrm{MNa}^{+}\right)$296.1257; found 296.1262.

(Sa)-3b: White solid, m. p. $=216-220{ }^{\circ} \mathrm{C} ;[\alpha]^{\mathrm{D}}{ }_{25}=-12.8\left(c 0.87, \mathrm{CH}_{3} \mathrm{OH}\right) .(R a)-3 \mathbf{b}$ : White solid, m. p. $=215-218^{\circ} \mathrm{C} ;[\alpha]^{\mathrm{D}}{ }_{25}=12.6\left(c 0.87, \mathrm{CH}_{3} \mathrm{OH}\right)$. Spectroscopic data for ( $\mathrm{Sa}$ )-3b and $(R a)-\mathbf{3 b}$ were identical to those given above for the racemic compound.

2.4.3. 2-Benzamido-2-(4-tert-butylcyclohexylidene)acetic acid (rac-3c). White solid, IR absorptions $(\mathrm{KBr}) v_{\max } 3422,1732 ; 1637,{ }^{1} \mathrm{H}$ NMR $\left(400 \mathrm{MHz}, \mathrm{DMSO}-d_{6}\right): \delta=0.85(\mathrm{~s}$, 9H), 1.03-1.18 (m, 2H), 1.22-1.30 (m, 1H), 1.79-1.99 (m, 4H), 2.70-2.74 (m, 1H), 3.42-3.46 (m, 1H), 7.46-7.50 (m, 2H), 7.53-7.58 (m, 1H), 7.90-7.94 (m, 2H), $9.60(\mathrm{~s}$, 1H), 12.30 (brs, 1H); ${ }^{13} \mathrm{C}$ NMR (100 MHz, DMSO-d $) \delta=27.2\left(\mathrm{CH}_{3}\right), 27.6\left(\mathrm{CH}_{2}\right), 28.1$ $\left(\mathrm{CH}_{2}\right), 29.4\left(\mathrm{CH}_{2}\right), 30.4\left(\mathrm{CH}_{2}\right), 32.0(\mathrm{C}), 46.8(\mathrm{CH}), 120.4(\mathrm{C}), 127.4(\mathrm{CH}), 128.1(\mathrm{CH})$, $131.3(\mathrm{CH}), 133.6(\mathrm{C}), 146.4(\mathrm{C}), 165.4(\mathrm{C}), 166.2(\mathrm{C})$; HRMS (FAB ${ }^{+}$) calcd for $\mathrm{C}_{19} \mathrm{H}_{25} \mathrm{NO}_{3} \mathrm{Na}\left(\mathrm{MNa}^{+}\right)$338.1727; found 338.1737.

(Sa)-3c: White solid, m. p. $=184-186{ }^{\circ} \mathrm{C} ;[\alpha]^{\mathrm{D}}{ }_{25}=-11.3\left(c 0.39, \mathrm{CH}_{3} \mathrm{OH}\right) .(R a)-3 \mathrm{c}$ : White solid, m. p. $=185-188{ }^{\circ} \mathrm{C} ;[\alpha]^{\mathrm{D}}{ }_{25}=-11.0\left(c 0.36, \mathrm{CH}_{3} \mathrm{OH}\right)$. Spectroscopic data for $(S a)-\mathbf{3 b}$ and $(R a)-\mathbf{3 b}$ were identical to those given above for the racemic compound.

\subsection{General procedure for the synthesis of dipeptides $4 \boldsymbol{a}, \mathbf{4 b}$ and $4 \boldsymbol{c}$}

Enantio-enriched $N$-benzoyl amino acid 3a-c $(0.3 \mathrm{mmol})$ from preparative HPLC and $N$-hydroxysuccinimide $(\mathrm{HOSu})(35 \mathrm{mg}, 0.3 \mathrm{mmol})$ were dissolved in dry dichloromethane $(5 \mathrm{~mL})$ under an inert atmosphere. The mixture was cooled to $0{ }^{\circ} \mathrm{C}$ and $N, N^{\prime}$-dicyclohexylcarbodiimide (DCC) $(62 \mathrm{mg}, 0.4 \mathrm{mmol})$ was added. The mixture was stirred at $0{ }^{\circ} \mathrm{C}$ for $90 \mathrm{~min}$ and $(S)$-phenylalanine cyclohexylamide $(53.8 \mathrm{mg}, 0.3 \mathrm{mmol})$ was added. The reaction mixture was stirred at room temperature for $24 \mathrm{~h}$. The resulting 
white solid was filtered off. The solution was diluted with dichloromethane and washed successively with $5 \%$ aqueous potassium bisulfate, $5 \%$ aqueous sodium bicarbonate and brine. The organic layer was dried over anhydrous magnesium sulfate and evaporated to dryness. The resulting dipeptides were purified by silica gel column chromatography using hexane/ethyl acetate $(1: 1)$ as eluent (yield about 20\%). Spectroscopic data for the obtained enantio-enriched dipeptides were compared to those previously reported in the literature [29] in order to assign unambiguously the configuration of $N$-benzoylamino acids and esters.

\section{Results and discussion}

\subsection{Synthesis}

Starting 2-phenyl-4-(4-substitutedcyclohexylidene)oxazol-5(4H)-ones 1a-c were prepared by condensation of hippuric acid and the corresponding 4substitutedcyclohexanone according to the reported procedure [29]. Smooth methanolysis of the ring with sodium methoxide in methanol led to the corresponding methyl 2-benzamido-2-(4-substitutedcyclohexylidene)acetates $\mathbf{2 a - c}$ as racemic mixtures, which were fully separated by HPLC with chiral stationary phases as detailed below. Racemic, enantioenriched or enantiomerically pure benzamido esters $\mathbf{2 a}-\mathbf{c}$ were treated with $4 \%$ alcoholic potassium hydroxide solution to give benzamido acids $\mathbf{3 a}-\mathbf{c}$ as racemic, enantioenriched or enantiomerically pure compounds. (Figure 1).

\subsection{Analytical enantioseparation}

Enantioseparation of methyl 2-benzamido-2-(4-substitutedcyclohexylidene) acetates $\mathbf{2 a}-\mathbf{c}$ using $250 \times 4.6 \mathrm{~mm}$ ID columns containing chiral stationary phases based on immobilized 3,5-dimethylphenylcarbamate derivatives of amylose or cellulose, namely Chiralpak ${ }^{\circledR}$ IA $[41]$ and Chiralpak ${ }^{\circledR}$ IB $[42]$, were first examined at the analytical level. The capacity $\left(k^{\prime}\right)$, selectivity $(\alpha)$ and resolution $\left(R_{s}\right)$ factors for each column in the enantioseparation of all compounds using mixtures of $n$-hexane/2-propanol as the eluent were determined. The separation factor and resolution for analytes $\mathbf{2 a - 2 c}$ in the optimized mobile phase composition are shown in Figure 2.

All enantiomers were resolved in at least in one of the two chiral columns but significant peak tailing was observed. As the primary cause of peak tailing is the occurrence of more than one mechanism of analyte retention, replacement of the 2propanol in the eluting mixture by acetone was tested in order to minimize peak tailing. This change did not have a positive effect on enantioseparation of any of the tested analytes for either the amylose or the cellulose-based phases, as shown in-Figure 1 Figure 2, with the optimized mobile phase composition. In fact, compound $2 \mathbf{c}$ was not separated on the Chiralpak ${ }^{\circledR}$ IB column with this mobile phase.

As can be seen form-Figure 1 Figure 2, in most cases the Chiralpak ${ }^{\circledR}$ IA column provides better selectivity and resolution than the Chiralpak ${ }^{\circledR}$ IB column for analytes 2a-c with both mobile phases with the optimized compositions. The former column was selected for further optimization to extend the study to the preparative-scale enantioseparation. 
Another cause of peak tailing is low solubility of the analyte in the mobile phase and, as a consequence, changes in the mobile phase composition to improve the sample solubility were investigated (Table 1).

Replacement of the 2-propanol in the eluting mixture by ethanol, which has a

\subsection{Semipreparative enantioseparation}

In order to enhance the solubility of analytes and increase the loading capacity of the column for the work at the semipreparative scale the addition of chloroform as a third component to the eluting mixture was evaluated. On the other hand the lower viscosity of ethanol in comparison to 2-propanol causes a lower column pressure, which is beneficial for the work at the semipreparative scale. The enantioseparation using ternary mixtures of $n$-hexane/ethanol/chloroform was subsequently studied. The presence of a small percentage of chloroform in the mobile phase led to a substantial enhancement in the sample solubility and increased substantially the loading capacity of the column while providing selectivity and resolution factors that allow enantioseparation at the semipreparative scale (Table 1). The optimized ternary mixtures $n$-hexane/ethanol/ chloroform as far as selectivity, resolution and analyte solubility is concerned were $86 / 7 / 7(\mathrm{v} / \mathrm{v} / \mathrm{v})$ for $2 \mathrm{a}(\mathrm{Rs}=2.36), 84 / 4 / 12(\mathrm{v} / \mathrm{v} / \mathrm{v})$ for $2 \mathrm{~b}(\mathrm{Rs}=1.62)$ and $92 / 4 / 4(\mathrm{v} / \mathrm{v} / \mathrm{v})$ for $2 \mathrm{c}(\mathrm{Rs}=1.38)$. Figure 3 shows the chromatographic resolution of rac- $2 \mathrm{a}$, rac-2b and rac-2c by analytical HPLC with optimized ternary mixtures.

One of the critical factors in preparative HPLC is the loading capacity. The value for this parameter should be one that allows a good compromise between the resolved amount of racemate per injection and the purity of the resolved enantiomers. In order to optimize the semipreparative enantioseparation, the column saturation capacity $(W s)$ was determined in an experimental approach starting from the previously determined elution conditions on the analytical column. Firstly, concentration overloading on the analytical column was achieved by injecting samples of increasing concentration under the same analytical conditions until the peaks remained resolved. Once concentration overloading had been ascertained, volume overloading can be determined in a similar way by increasing the injected volume of the samples. The chromatographic data obtained on working in an overload mode on the analytical column are shown in Table 2. 
Finally, an additional scale-up of the system from the analytical to the semipreparative column was necessary. The two parameters that must be scaled when the injected volume, taking into account the fact that the ratio between their volumes is equal to the ratio between the square of their diameters.

On working in an overload mode both in mass and volume, the capacity of the semipreparative column and the optimum concentration of the sample and injected volume were determined to be $12.5 \mathrm{mg}(25 \mathrm{mg} / \mathrm{mL}, 500 \mu \mathrm{L})$ for compound $\mathbf{2 a}, 22.5 \mathrm{mg}$ $(150 \mathrm{mg} / \mathrm{mL}, 150 \mu \mathrm{L})$ for compound $\mathbf{2 b}$ and $15 \mathrm{mg}(75 \mathrm{mg} / \mathrm{mL}, 200 \mu \mathrm{L})$ for compound 2c.

The semipreparative resolution of compounds $2 \mathbf{a}-\mathbf{c}$ on a $250 \mathrm{~mm} \times 20 \mathrm{~mm}$ ID Chiralpak $^{\circledR}$ IA column was achieved by successive injections of a solution of the sample in chloroform, 24 injections of $500 \mu \mathrm{L}$ for compound $\mathbf{2 a}, 13$ injections of $150 \mu \mathrm{L}$ for compound $\mathbf{2 b}$ and 20 injections of $200 \mu \mathrm{L}$ for compound $\mathbf{2 c}$. In order to enhance throughput, injections were partially overlapped and for each run four separate fractions were collected and combined with equivalent fractions. The combined fractions were concentrated and reinjected onto the analytical chiral column to determine their enantiomeric purity. The profile of the chromatogram obtained for the analytical column operating in an overload mode to establish the loading capacity of the column is shown in Figure 4 along with the chromatogram of the semipreparative resolution of compound 2a. The corresponding analytical check of the four collected fractions in the resolution of compound 2a is shown in Figure 5.

The first and the second eluted enantiomers were isolated in enantiomerically pure form in the first and the fourth fractions, respectively. The second and the third fractions contained mixtures enriched in either the first or the second eluted enantiomer. Taking into account the concentration of the sample and the injection volume for each analyte, $60-70 \mathrm{mg}$ of each racemate were resolved per hour. Using this protocol $300 \mathrm{mg}$ of each racemate was resolved. The recovered amount and the enantiomeric ratios of the different enantiomers in each fraction collected are shown in Table 3.

\subsection{Absolute configuration determination}

In order to determine the absolute configuration of the resolved $N$-benzoylamino esters, partially resolved compounds were transformed into the corresponding free amino acids, namely $N$-benzoylamino acids $3 \mathbf{a}-\mathbf{c}$, by saponification with $4 \%$ alcoholic potassium hydroxide according to Figure 1 . The acids were then then coupled with $(S)$ phenylalanine cyclohexylamide in the presence of $N, N^{\prime}$-dicyclohexylcarbodiimide (DCC) and $N$-hydroxysuccinimide (HOSu) to give enriched mixtures in known compounds $\left(R_{\mathrm{a}}, S\right)-\mathbf{4 a}-\mathbf{c}$ and $\left(S_{\mathrm{a}}, S\right)-\mathbf{4 a}-\mathbf{c}$ (Figure 6), the stereochemistry of which had been previously assigned on the basis of X-ray diffraction experiments. [29] Comparison of the physical and spectroscopic data with those previously reported in the literature for the same compounds allowed us to unambiguously assign the $S_{\mathrm{a}}$ configuration to the first eluted $N$-benzoylamino ester and the $R_{\mathrm{a}}$ configuration to the more strongly retained $N$-benzoylamino ester.

\section{Conclusions}

For the first time, efficient HPLC methods for the analytical and semipreparative resolution of axially chiral amino acid derivatives have been developed. The use of ternary mixtures of $n$-hexane/ethanol/chloroform as eluent and amylose tris(3,5- 
dimethylphenylcarbamate) as the chiral selector allowed good baseline 450 enantioseparations to be achieved at the analytical scale. The analytical method was 451 successfully scaled up to semipreparative loadings and about $60-70 \mathrm{mg}$ of each racemate were resolved per hour. Up to $120 \mathrm{mg}$ of the axially chiral amino acid have been isolated in enantiomerically pure from $300 \mathrm{mg}$ of the racemic mixture.

\section{Acknowledgements}

The financial support of the Government of Aragón (GA E-102) is acknowledged.

\section{References}

[1] G. M. Coppola, H. F. Schuster, Asymmetric Synthesis. Construction of chiral molecules using amino acids, Wiley, New York, 1987.

[2] F. J. Sardina, H. Rapoport,: Enantiospecific synthesis of heterocycles from $\alpha$ amino acids, Chem. Rev. 96 (1996) 1825-1872.

[3] J. Kaiser, S. S. Kinderman, B. C. J. van Esseveldt, F. L. van Delft, H. E.

Schoemaker, R. H. Blaauw, F. P. J. T. Rutjes, Synthetic applications of aliphatic unsaturated $\alpha$-H- $\alpha$-amino acids, Org. Biomol. Chem. 3 (2005) 3435-3467.

| [4] A. Studer, : Amino acids and their derivatives as stoichiometric auxiliaries in asymmetric synthesis, Synthesis (1996) 793-815.

[5] A. More, H. Abe, A. Inoue, Amino acids, peptides and their derivatives:

Powerful chiral ligands for metal-catalyzed asymmetric synthesis, Appl. Organomet. Chem. 9 (1995) 189-197.

[6] J. L. Vicario, D. Badia, L. Carrillo, E. Reyes, J. Etxebarria, $\alpha$-Amino acids, $\beta$-amino alcohols and related compounds as chiral auxiliaries, ligands and catalysts in the asymmetric aldol reaction, Curr. Org. Chem. 9 (2005) 219-235.

[7] E. R. Jarvo, S. J. Miller, Amino acids and peptides as asymmetric organocatalysts, Tetrahedron 58 (2002) 2481-2495.

[8] L. W. Xu, X Lu, Primary amino acids: privileged catalysts in enantioselective organocatalysis, Org. Biomol. Chem., 6 (2008) 2047-2053.

[9] G. Cardillo, L. Gentilucci, A. Tolomelli, Unusual amino acids: Synthesis and introduction into naturally occurring peptides and biologically active analogues, Mini Rev. Med. Chem. 6 (2006) 293-304.

497300.

498 | [11] W. H. Zhang, G. Otting, C. J. Jackson, Protein engineering with unnatural amino 499 acids, Curr. Opin. Struct. Biol 23 (2013) 581-587. 
[12] H. Kotsuki, H. Ikishima, A. Okuyama, Review:-Organocatalytic asymmetric synthesis using proline and related molecules. Part 1, Heterocycles, 75 (2008) 493-529.

502 [13] J. Paradowska, M. Stodulski, J. Mlynarski, Review: Catalysts based on amino acids for asymmetric reactions in water, Angew. Chem. Int. Ed. 48 (2009) 4288-4297.

504 [14] L. W. Xu, Review:-Powerful amino acid derived bifunctional phosphine catalysts bearing a hydrogen bond donor in asymmetric synthesis, Chemcatchem 5 (2013) 27752784.

[15] L. Ridvan, N. Abdallah, R. Holakovský, M. Tichý, J. Závada, 6-Amino-1,11dimethyl-6,7-dihydro-5H-dibenzo[a,c]cycloheptene-6-carboxylic acid: The first chiral $\alpha$-amino acid without asymmetric carbon atom, Tetrahedron: Asymmetry 7 (1996) 231236.

511 [16] J. P. Mazaleyrat, A. Gaucher, M. Wakselman, L. Tchertanov, J. Guilhem, A new chiral $\alpha$-aminoacid with only axial dissymmetry: Synthesis and X-ray analysis of a 1,1'binaphthyl-substituted $\alpha$-aminoisobutyric acid (Bin) and of its biphenyl analogue (Bip), Tetrahedron Lett. 37 (1996) 2971-2974.

[17] J. P. Mazaleyrat, A. Gaucher, J. Savrda, M. Wakselman, Novel $\alpha, \alpha$-disubstituted $\alpha$ aminoacids with axial dissymmetry and their $N$ - or $C$-protected derivatives, Tetrahedron: Asymmetry 8 (1997) 619-631.

[18] J. P. Mazaleyrat, A. Gaucher, Y. Goubard, J. Savrda, M. Wakselman, N-t-Boc 6amino-1,11-(20-crown-6)-6,7-dihydro-5H-didenzo[a,c]cycloheptene-6-carboxylic acid methyl ester, the first prototype of a crown-carrier-axially dissymmetric- $\alpha, \alpha-$ disubstituted glycine, Tetrahedron Lett. 38 (1997) 2091-2094.

[19] M. Tichý, L. Ridvan, M. Buděšínský, J. Závada, J. Podlaha, I. Císařová, Axially chiral bis( $\alpha$-amino acid)s and their deamino analogues. synthesis and configurational assignment, Collect. Czech. Chem. Commun. 63 (1998) 211-221.

[20] J. P. Mazaleyrat, A. Boutboul, Y. Lebars, A. Gaucher, M. Wakselman, Practical resolution of an atropoisomeric $\alpha, \alpha$-disubstituted glycine with L-phenylalanine cyclohexylamide as chiral auxiliary, Tetrahedron: Asymmetry 9 (1998) 2701-2713.

[21] L. Ridvan, M. Buděšínský, M. Tichý, P. Maloň, J. Závada, J. Podlaha, I. Císařová, Axially chiral Bis( $\alpha$-amino acid)s and dioxopiperazines. Synthesis and configurational assignment, Tetrahedron 55 (1999) 12331-12348.

[22] F. Formaggio, M. Crisma, C. Toniolo, L. Tchertanov, J. Guilhem, J. P. Mazaleyrat, A. Gaucherc, M. Wakselman, Bip: a $C^{\alpha}$-tetrasubstituted, axially chiral $\alpha$-amino acid. Synthesis and conformational preference of model peptides, Tetrahedron 56 (2000) 8721-8734.

[23] J. P. Mazaleyrat, Y. Goubard, M. V. Azzini, M. Wakselman, C. Peggion, F. Formaggio, C. Toniolo, Synthesis of the first axially dissymmetric, $\mathrm{C}^{\alpha, \alpha}$-disubstituted glycine containing a crown ether receptor, and the conformational preferences of a model peptide, Eur. J. Org. Chem. (2002) 1232-1247.

[24] F. Formaggio, C. Peggion, M. Crisma, C. Toniolo, L. Tchertanov, J. Guilhem, J. P. Mazaleyrat, Y. Goubard, M. Wakselman, A chirally stable, atropoisomeric, $\mathrm{C}^{\alpha}$ tetrasubstituted $\alpha$-amino acid: Incorporation into model peptides and conformational preference, Helv. Chim. Acta 84 (2001) 481-501.

[25] J. P. Mazaleyrat, K. Wright, A. Gaucher, M. Wakselman, S. Oancea, F. Formaggio, C. Toniolo, V. Setnička, J. Kapitán T. A. Keiderling, Synthesis and conformational study of homo-peptides based on $\left(S\right.$ )-Bin, a $C 2$-symmetric binaphthyl-derived $\mathrm{C}^{\alpha, \alpha}$ disubstituted glycine with only axial chirality, Tetrahedron: Asymmetry 14 (2003) $1879-1893$.

[26] J. P. Mazaleyrat, K. Wright, A. Gaucher, N. Toulemonde, M. Wakselman, S. Oancea, C. Peggion, F. Formaggio, V. Setnička, T. A. Keiderling, C. Toniolo, Induced 
axial chirality in the biphenyl core of the $C^{\alpha}$-tetrasubstituted $\alpha$-amino acid residue Bip and subsequent propagation of chirality in (Bip) $)_{n} /$ Val oligopeptides, J. Am. Chem. Soc. 126 (2004) 12874-12879.

[27] J. P. Mazaleyrat, K. Wright, A. Gaucher, N. Toulemonde, L. Dutot, M. Wakselman, Q. B. Broxterman, B. Kaptein, S. Oancea, C. Peggion, M. Crisma, F. Formaggio, C. Toniolo, Induced axial chirality in the biphenyl core of the proatropoisomeric, $\mathrm{C}^{\alpha}$ tetrasubstituted $\alpha$-amino acid residue Bip in peptides, Chem. Eur. J. 11 (2005) 69216929.

[28] C. Cativiela, M. D. Díaz-de-Villegas, J. A. Gálvez, Synthesis and chemical resolution of unique $\beta, \alpha$-didehydroamino acids with a chiral axis, Tetrahedron Lett. 40 (1999) 1027-1030.

[29] C. Cativiela, M. D. Díaz-de-Villegas, J. A. Gálvez, G. Su, Synthesis and conformational properties of model dipeptides containing novel axially chiral $\beta, \alpha-$ didehydroamino acids at the $(i+1)$ position of a $\beta$-turn conformation, Tetrahedron 60 (2004) 11923-11932.

565

[30] C. Cativiela, M. D. Díaz-de-Villegas, J. A. Gálvez, G. Su, Horner-WadsworthEmmons reaction for the synthesis of unusual $\beta, \alpha$-didehydroamino acids with a chiral axis, Arkivoc iv (2004) 59-66. [31] Y. Okamoto, T. Ikai, Review:-Chiral HPLC for efficient resolution of enantiomers. Chem. Soc. Rev. 37 (2008) 2593-2608.

[32] G. B. Cox, Preparative enantioselective chromatography. Oxford: Blackwell; 2005. [33] E. Francotte, Isolation and production of optically pure drugs by enantioselective chromatography. In: E. Francotte, W. Lindner editors. Chirality in drug research. Weinheim: Wiley-VCH; 2006. p 155-187.

[34] I. Ilisz, A. Aranyi, Z. Pataj, A. Péter, Enantiomeric separation of nonproteinogenic amino acids by high-performance liquid chromatography, J. Chromatogr. A, 1269 (2012) 94-121.

[35] A. Péter, G. Török, J. P. Mazaleyrat, M. Wakselman, Highperformance liquid chromatographic separation of enantiomers of 1,1'-binaphthylsubstituted $\alpha$-aminoisobutyric acid, J. Chromatogr. A 790 (1997) 41-46.

[36] Substructure search on SciFinder ${ }^{\circledR}$ with any atom except hydrogen at $\mathrm{C}_{4}$ on the cyclohexylidene moiety, any atom except carbon or hydrogen on the carbonyl of the acid moiety and any atom on the amino moiety.

[37] [36]-B. Chankvetadze, Recent developments on polysaccharide-based chiral stationary phases for liquid-phase separation of enantiomers, J. Chromatogr. A 1269 (2012) 26-51.

[38] [37]-T. Zhang, P, Franco, Analytical and preparative potential of immobilized polysaccharide-derived chiral stationary phases. In: G. Subramanian editor, Chiral separation techniques. Weinheim: Wiley-VCH; 2007, p 99-134.

[39] [38]-X. Chen, C. Yamamoto, Y. Okamoto, Polysaccharide derivatives as useful chiral stationary phases in high-performance liquid chromatography, Pure Appl. Chem. 79 (2007) 1561-1573.

[40] [39]-Residual solvent signals set according to G. R. Fulmer, A. J. M. Miller, N. H. Sherden, H. E. Gottlieb, A. Nudelman, B. M. Stolz, J. E. Bercaw, K. I. Goldberg, NMR Chemical shifts of trace impurities: Common laboratory solvents, organics and gases in deuterated solvents relevant to the organometallic chemistry, Organometallics 29 (2010) 2176-2179.

[41] [40]-T. Zhang, C. Kientzy, P. Franco, A. Ohnishi, Y. Kagamihara, H. Kurosawa, Solvent versatility of immobilized 3,5-dimethylphenylcarbamate of amylose in enantiomeric separations by HPLC. J. Chromatogr A 1075 (2005) 65-75. 
600 [42] [41] T. Zhang, D. Nguyen, P. Franco, T. Murakami, A. Ohnishi, H. Kurosawa, 601 Cellulose 3,5-dimethylphenylcarbamate immobilized on silica: a new chiral stationary 602 phase for the analysis of enantiomers. Anal. Chim. Acta 557 (2006) 221-228.

603 [43] [42]-T. Wang, R. M. Wenslow, Effects of alcohol mobile-phase modifiers on the 604 structure and chiral selectivity of amylose tris(3,5-dimethylphenylcarbamate) chiral 605 stationary phase. J. Chromatogr. A 1015 (2003) 99-110.

606 [44] [43]-R. Helmy, T. Wang, Selectivity of amylose tris(3,5-dimethylphenylcarbamate) 607 chiral stationary phase as a function of its structure altered by changing concentration of 608 ethanol or 2-propanol mobile-phase modifier. J. Sep. Sci. 28 (2005) 189-192.

609

610

611

612

613

614

615

616 
619 Scheme 1. Fig. 1. Synthesis and structures of compounds 2a-c. and right graphics, respectively) on $250 \times 4.6 \mathrm{~mm}$ ID Chiralpak ${ }^{\circledR}$ IA and Chiralpak ${ }^{\circledR}$ IB columns. Chromatographic conditions: injection volume: $5 \mu \mathrm{L}$, samples dissolved in chloroform, flow rate $1 \mathrm{~mL} / \mathrm{min}$; UV detection $220 \mathrm{~nm}$. Mobile phase composition: A, $n$-Hx/2-PrOH 95/5 (v/v); B, $n$-Hx/2-PrOH 90/10 (v/v); C, $n$-Hx/2-PrOH 97/3 (v/v); D, $n-$ $\mathrm{Hx} /$ acetone $90 / 10(v / v) ; \mathrm{E}, n$-Hx/acetone $95 / 5(v / v)$.

Fig. 2. Fig. 3. Chromatograms for the enantioseparation of compounds $\mathbf{2 a}, \mathbf{2 b}$ and $\mathbf{2 c}$ on a $250 \times 4.6 \mathrm{~mm}$ ID Chiralpak $^{\circledR}$ IA column. (A) Mobile phase composition $n$ $\mathrm{Hx} / \mathrm{EtOH} / \mathrm{CHCl}_{3}$ 86/7/7 $(v / v / v)$, flow rate: $1 \mathrm{~mL} / \mathrm{min}$; UV detection: $260 \mathrm{~nm}$, chromatographic parameters: $k^{\prime}=2.92, \alpha=1.16, R_{s}=2.36$; (B) mobile phase composition $\left.n-\mathrm{Hx} / \mathrm{EtOH} / \mathrm{CHCl}_{3} 84 / 4 / 12(v / v / v)\right)$, flow rate: $1 \mathrm{~mL} / \mathrm{min}$; UV detection: $235 \mathrm{~nm}$, chromatographic parameters: $k^{\prime}=1.86, \alpha=1.19, R_{s}=1.62$; (C) mobile phase composition $n-\mathrm{Hx} / \mathrm{EtOH} / \mathrm{CHCl}_{3} 92 / 4 / 4(v / v / v)$, flow rate: $1 \mathrm{~mL} / \mathrm{min}$; UV detection: 235 $\mathrm{nm}$, chromatographic parameters: $k^{\prime}=3.15, \alpha=1.13, R_{s}=1.38$.

Fig. 3. Fig. 4. (A) Chromatogram for the enantioseparation of compound 2a operating in an overload mode on a $4.6 \times 20 \mathrm{~mm}$ ID Chiralpak ${ }^{\circledR}$ IA column. Injection volume: $25 \mu \mathrm{L}$, $c=25 \mathrm{mg} / \mathrm{mL}$, flow rate, $1 \mathrm{~mL} / \mathrm{min}$; UV detection $280 \mathrm{~nm}$, eluent $n-\mathrm{Hx} / \mathrm{EtOH} / \mathrm{CHCl}_{3}$

86/7/7. (B) Semipreparative chromatogram for the enantioseparation of compound 2a on 641 a $250 \times 20 \mathrm{~mm}$ ID Chiralpak ${ }^{\circledR}$ IA column. Injection volume: $500 \mu \mathrm{L}, c=25 \mathrm{mg} / \mathrm{mL}$, 642 flow rate, $18 \mathrm{~mL} / \mathrm{min}$; UV detection $280 \mathrm{~nm}$, eluent $n-\mathrm{Hx} / \mathrm{EtOH} / \mathrm{CHCl}_{3} 86 / 7 / 7$, repetitive 643 644

645 Fig. 4. Fig. 5. Analytical check of the fractions collected in the enantioseparation of compound 2a on a $250 \times 4.6 \mathrm{~mm}$ ID Chiralpak ${ }^{\circledR}$ IA column. Injection volume: $5 \mu \mathrm{L}, c=$ $5 \mathrm{mg} / \mathrm{mL}$, flow rate, $1 \mathrm{~mL} / \mathrm{min}$; UV detection $240 \mathrm{~nm}$, eluent $n-\mathrm{Hx} / \mathrm{EtOH} / \mathrm{CHCl}_{3} 86 / 7 / 7$. (a) First fraction collected. (b) Second fraction collected. (c) Third fraction collected. (b) Fourth fraction collected. 

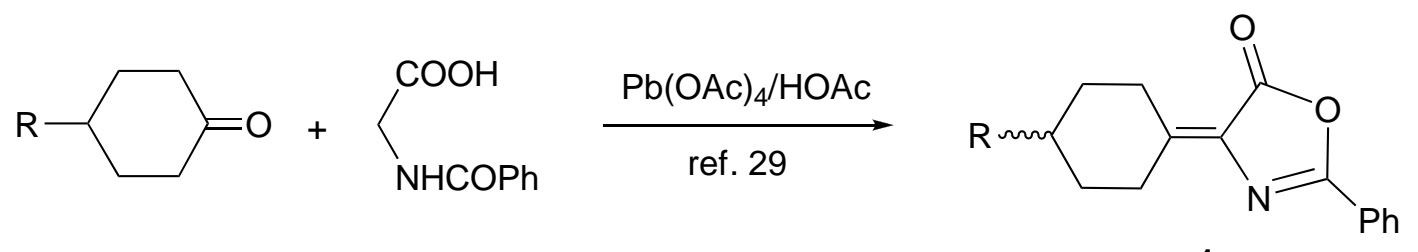

rac-1a-c

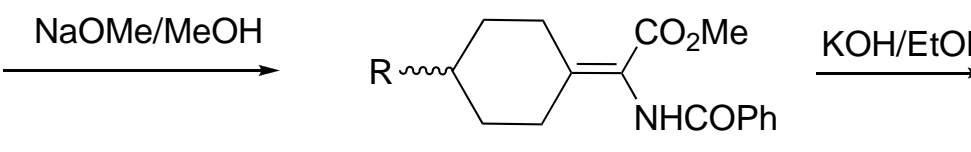

rac-2a-c

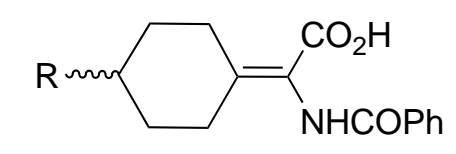

rac-3a-c

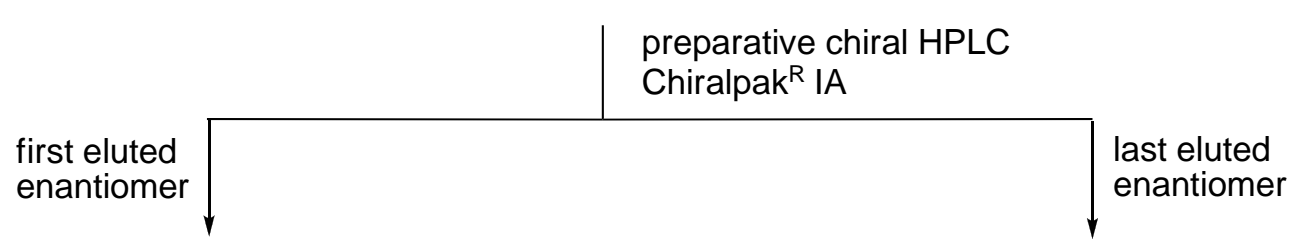

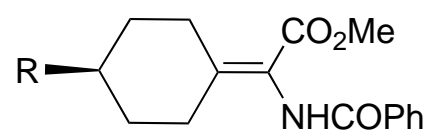

$\left(S_{a}\right)-2 a-c$

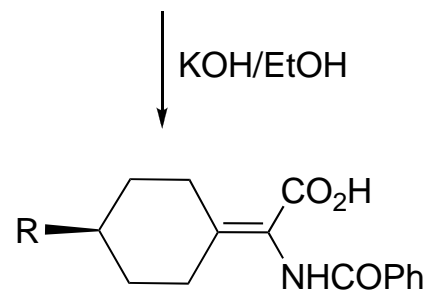

$\left(S_{a}\right)-3 a-c$

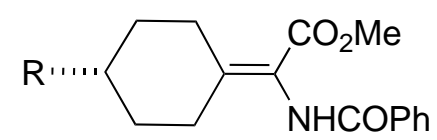

$\left(R_{\mathrm{a}}\right)-2 \mathrm{a}-\mathrm{c}$

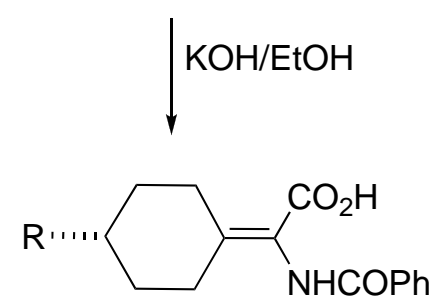

$\left(R_{\mathrm{a}}\right)$-3a-c

$\mathrm{a}, \mathrm{R}=\mathrm{Ph} ; \mathrm{b}, \mathrm{R}=\mathrm{Me}, \mathrm{c}, \mathrm{R}={ }^{t} \mathrm{Bu}$ 

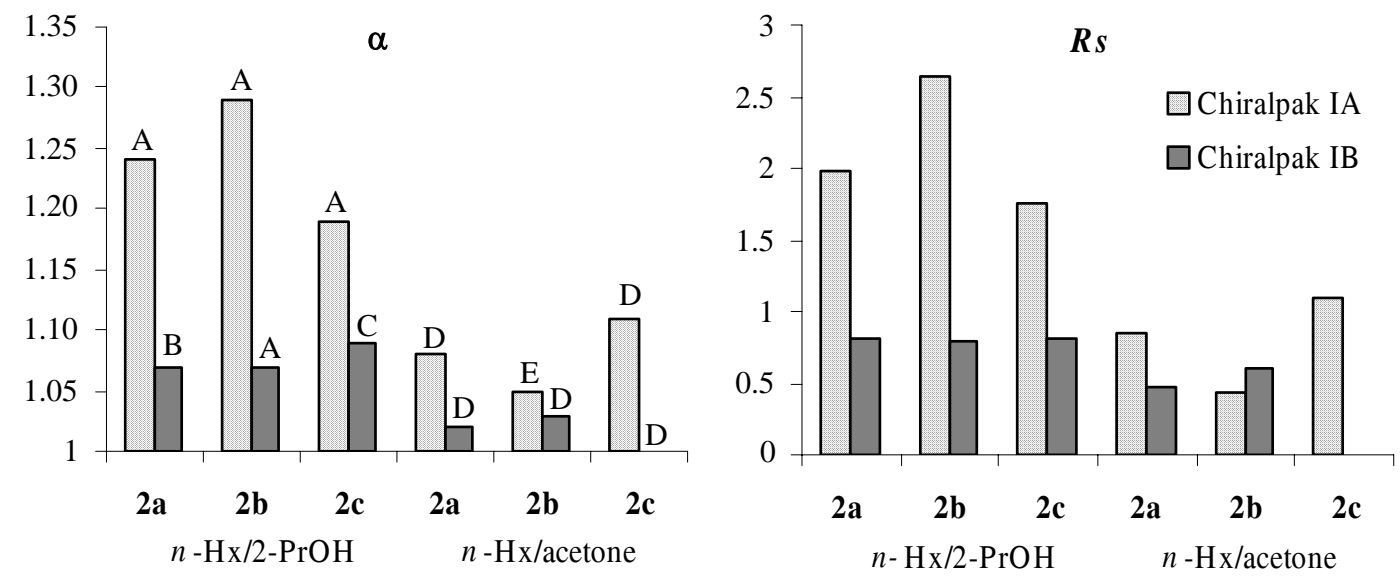

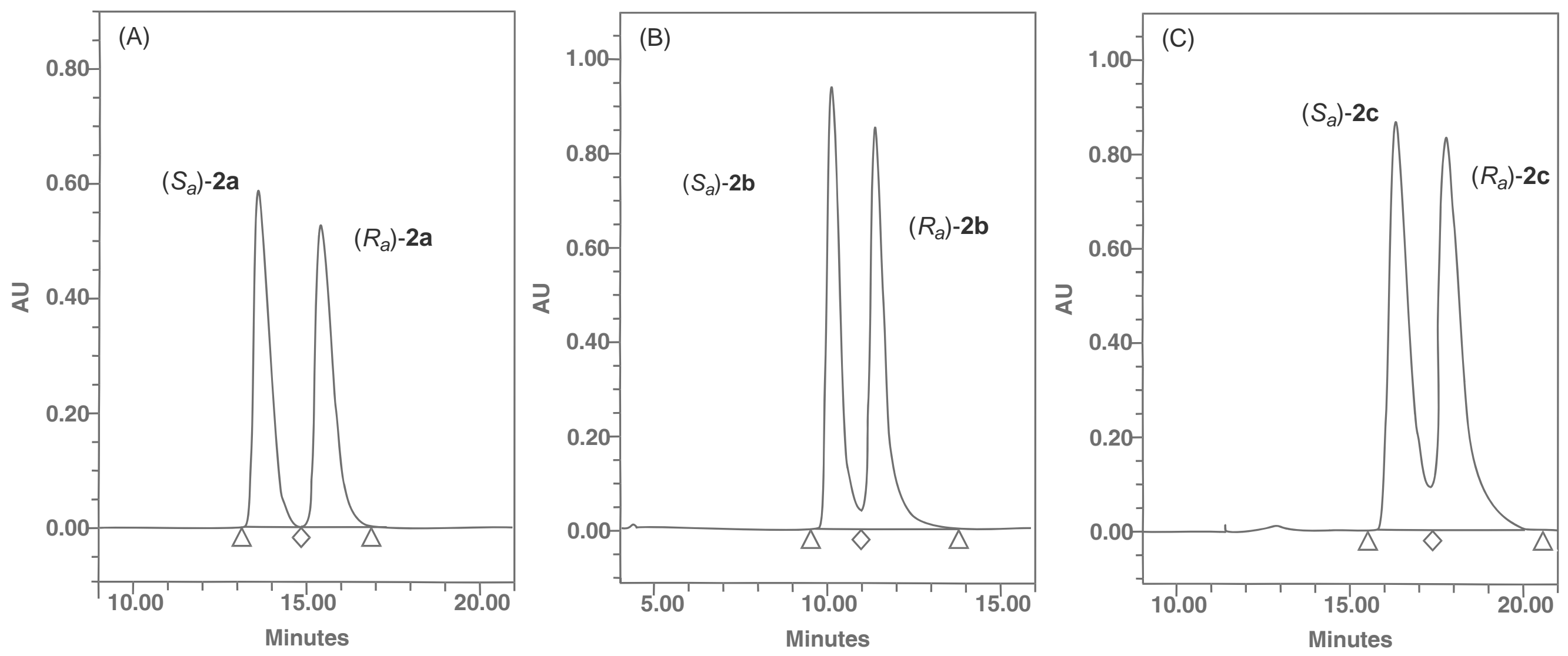

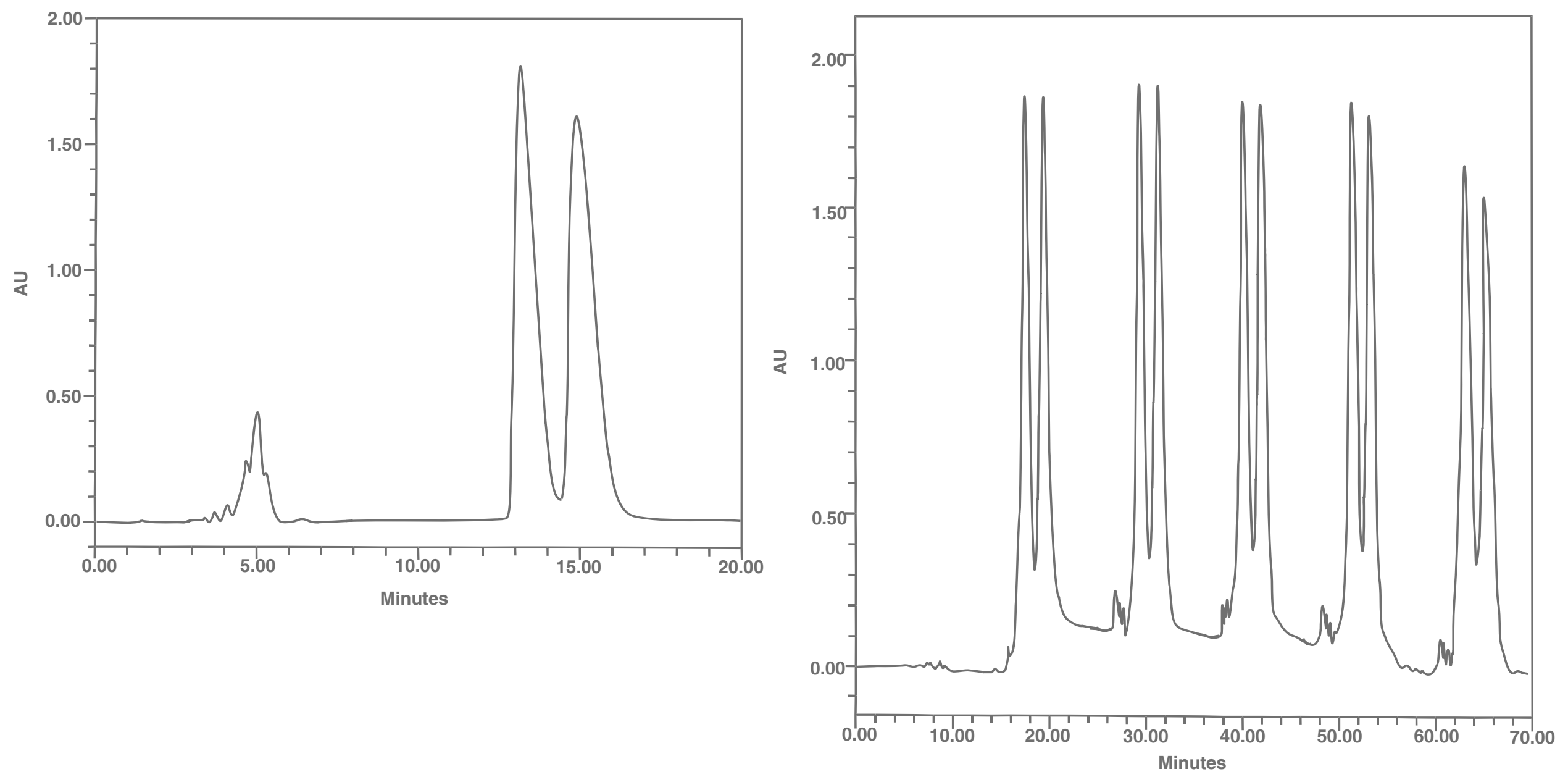
Figure
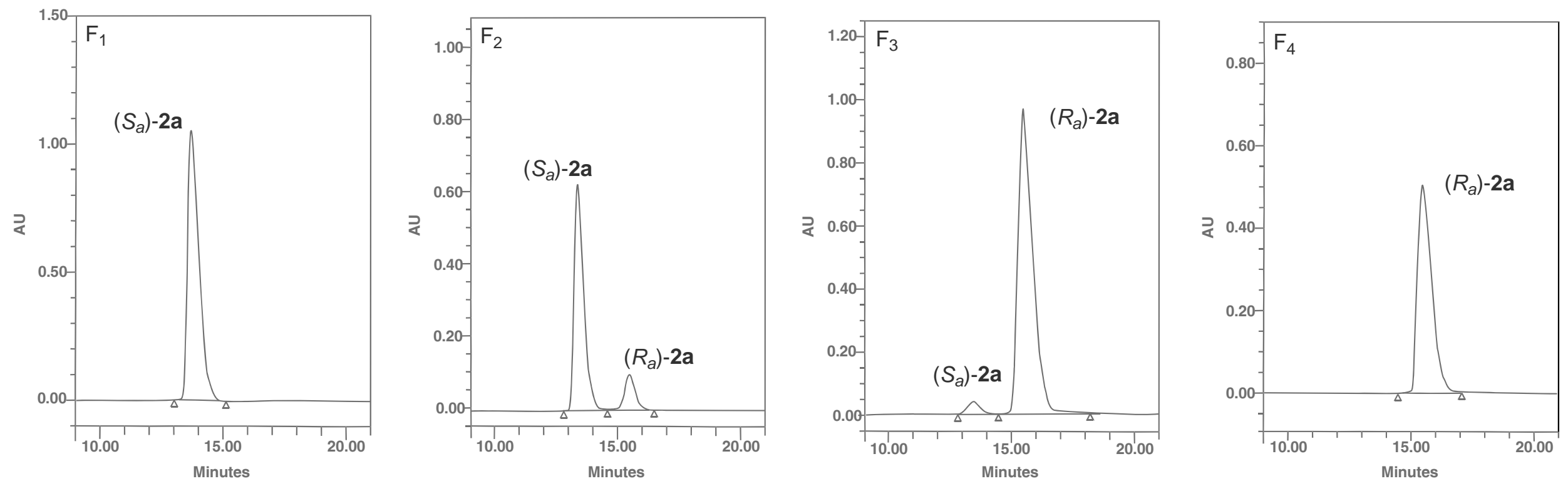


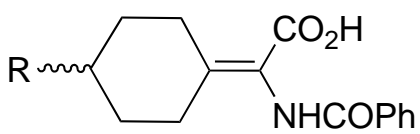

3a-c
1) HOSu

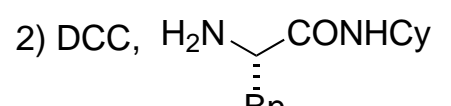
Bn<smiles>[R]C1CCC(=C(NC(=O)Oc2ccccc2)C(=O)NC(Cc2ccccc2)C(=O)O)CC1</smiles>

$$
\left(R_{a}, S\right)-4 a-c
$$<smiles>[R]C1CCC(=C(NC(=O)c2ccccc2)C(=O)N[C@@H](Cc2ccccc2)C(=O)NC2CCCCC2)CC1</smiles>

$\left(S_{a}, S\right)-4 a-c$

$\mathrm{a}, \mathrm{R}=\mathrm{Ph} ; \mathrm{b}, \mathrm{R}=\mathrm{Me}, \mathrm{c}, \mathrm{R}={ }^{t} \mathrm{Bu}$ 
Table 1

Selected chromatographic data for the analytical HPLC resolution of amino acid derivatives $r a c-\mathbf{2} \mathbf{a}-\mathbf{c}$ on Chiralpak ${ }^{\circledR}$ IA using different mobile phases. ${ }^{a}$

\begin{tabular}{|c|c|c|c|c|c|}
\hline Compound & Eluent & $\%(\mathrm{v} / \mathrm{v})$ & $k^{\prime}$ & $\alpha$ & $R_{S}$ \\
\hline$r a c-\mathbf{2 a}$ & $n-\mathrm{Hx} / 2-\mathrm{PrOH}$ & $95 / 5$ & 5.11 & 1.24 & 1.98 \\
\hline$r a c-\mathbf{2 b}$ & $n-\mathrm{Hx} / 2-\mathrm{PrOH}$ & $95 / 5$ & 3.10 & 1.29 & 2.65 \\
\hline$r a c-2 c$ & $n-\mathrm{Hx} / 2-\mathrm{PrOH}$ & $95 / 5$ & 5.46 & 1.19 & 1.75 \\
\hline$r a c-\mathbf{2 a}$ & $n-\mathrm{Hx} / \mathrm{EtOH}$ & $92 / 8$ & 4.16 & 1.14 & 1.41 \\
\hline$r a c-\mathbf{2 a}$ & $n$-Hx/EtOH & $90 / 10$ & 3.14 & 1.12 & 1.43 \\
\hline$r a c-\mathbf{2 a}$ & $n$-Hx/EtOH & $85 / 15$ & 1.83 & 1.12 & 1.25 \\
\hline$r a c-\mathbf{2 b}$ & $n-\mathrm{Hx} / \mathrm{EtOH}$ & $93 / 7$ & 2.85 & 1.08 & 1.00 \\
\hline$r a c-\mathbf{2 b}$ & $n-\mathrm{Hx} / \mathrm{EtOH}$ & $90 / 10$ & 2.47 & 1.07 & 0.60 \\
\hline$r a c-2 c$ & $n-\mathrm{Hx} / \mathrm{EtOH}$ & $95 / 5$ & 3.85 & 1.10 & 1.15 \\
\hline$r a c-\mathbf{2 a}$ & $n-\mathrm{Hx} / \mathrm{EtOH} / \mathrm{CHCl}_{3}$ & $86 / 9 / 5$ & 2.55 & 1.16 & 2.10 \\
\hline$r a c-\mathbf{2 a}$ & $n-\mathrm{Hx} / \mathrm{EtOH} / \mathrm{CHCl}_{3}$ & $88 / 7 / 5$ & 3.55 & 1.17 & 2.10 \\
\hline$r a c-\mathbf{2 a}$ & $n-\mathrm{Hx} / \mathrm{EtOH} / \mathrm{CHCl}_{3}$ & $86 / 7 / 7$ & 2.92 & 1.16 & 2.36 \\
\hline$r a c-\mathbf{2 b}$ & $n-\mathrm{Hx} / \mathrm{EtOH} / \mathrm{CHCl}_{3}$ & $92 / 4 / 4$ & 3.71 & 1.10 & 1.29 \\
\hline$r a c-\mathbf{2 b}$ & $n-\mathrm{Hx} / \mathrm{EtOH} / \mathrm{CHCl}_{3}$ & $88 / 4 / 8$ & 2.68 & 1.12 & 1.39 \\
\hline$r a c-\mathbf{2 b}$ & $n-\mathrm{Hx} / \mathrm{EtOH} / \mathrm{CHCl}_{3}$ & $86 / 4 / 10$ & 2.30 & 1.17 & 1.59 \\
\hline$r a c-\mathbf{2 b}$ & $n-\mathrm{Hx} / \mathrm{EtOH} / \mathrm{CHCl}_{3}$ & $84 / 4 / 12$ & 1.86 & 1.19 & 1.62 \\
\hline$r a c-2 c$ & $n-\mathrm{Hx} / \mathrm{EtOH} / \mathrm{CHCl}_{3}$ & $93 / 4 / 3$ & 4.17 & 1.14 & 1.45 \\
\hline$r a c-2 c$ & $n-\mathrm{Hx} / \mathrm{EtOH} / \mathrm{CHCl}_{3}$ & $92 / 4 / 4$ & 3.15 & 1.13 & 1.38 \\
\hline
\end{tabular}




\section{Table 2}

Chromatographic data for the resolution of amino acid derivatives rac-2a-c on Chiralpak ${ }^{\circledR}$ IA data working in an overload mode in the analytical column.

\begin{tabular}{|c|c|c|c|c|c|}
\hline Compound & Eluent & $\%(\mathrm{v} / \mathrm{v})$ & $k^{\prime}$ & $\alpha$ & $R_{s}$ \\
\hline$r a c-2 \mathbf{a}^{\mathrm{a}}$ & $n-\mathrm{Hx} / \mathrm{EtOH} / \mathrm{CHCl}_{3}$ & $86 / 7 / 7$ & 2.67 & 1.14 & 1.30 \\
\hline$r a c-2 \mathbf{b}^{\mathrm{b}}$ & $n-\mathrm{Hx} / \mathrm{EtOH} / \mathrm{CHCl}_{3}$ & $84 / 4 / 12$ & 2.20 & 1.19 & 1.10 \\
\hline $\operatorname{rac}-\mathbf{2} \mathbf{c}^{\mathrm{c}}$ & $n-\mathrm{Hx} / \mathrm{EtOH} / \mathrm{CHCl}_{3}$ & $92 / 4 / 4$ & 3.15 & 1.14 & 1.15 \\
\hline
\end{tabular}




\section{Table 3}

Semipreparative resolution of the enantiomers of compounds $\mathbf{2} \mathbf{a}-\mathbf{c}^{\text {a }}$

\begin{tabular}{lllll}
\hline Compound & $1^{\text {st }}$ fraction & $2^{\text {nd }}$ fraction & $3^{\text {rd }}$ fraction & $4^{\text {th }}$ fraction \\
\hline$r a c-2 \mathbf{a}^{\mathrm{b}}$ & $100 / 0(105 \mathrm{mg})$ & $85 / 15(28 \mathrm{mg})$ & $4 / 96(72 \mathrm{mg})$ & $0 / 100(60 \mathrm{mg})$ \\
$r a c-2 \mathbf{b}^{\mathrm{c}}$ & $98.5 / 1.5(105 \mathrm{mg})$ & $85 / 15(14 \mathrm{mg})$ & $6 / 94(41 \mathrm{mg})$ & $0 / 100(90 \mathrm{mg})$ \\
$r a c-2 \mathbf{c}^{\mathrm{d}}$ & $100 / 0(120 \mathrm{mg})$ & $82 / 18(33 \mathrm{mg})$ & $3 / 97(40 \mathrm{mg})$ & $0 / 100(100 \mathrm{mg})$ \\
\hline
\end{tabular}

${ }^{\mathrm{a}} 250 \times 20 \mathrm{~mm}$ ID Chiralpak ${ }^{\circledR}$ IA column. ${ }^{\mathrm{b}}$ Injection volume: $500 \mu \mathrm{L}, c=25 \mathrm{mg} / \mathrm{mL}$, flow rate, 18 $\mathrm{mL} / \mathrm{min}$; UV detection $280 \mathrm{~nm}$, eluent $n-\mathrm{Hx} / \mathrm{EtOH} / \mathrm{CHCl}_{3} 86 / 7 / 7$. ${ }^{\mathrm{c}}$ Injection volume: $150 \mu \mathrm{L}, c=150$ $\mathrm{mg} / \mathrm{mL}$, flow rate, $16 \mathrm{~mL} / \mathrm{min}$; UV detection $290 \mathrm{~nm}$, eluent $n-\mathrm{Hx} / \mathrm{EtOH} / \mathrm{CHCl}_{3} 84 / 4 / 12$. ${ }^{\mathrm{c}}$ Injection volume: $200 \mu \mathrm{L}, c=75 \mathrm{mg} / \mathrm{mL}$, flow rate, $16 \mathrm{~mL} / \mathrm{min}$; UV detection $265 \mathrm{~nm}$, eluent $n-\mathrm{Hx} / \mathrm{EtOH} / \mathrm{CHCl}_{3}$ $92 / 4 / 4$. 